\title{
Muscle morphology in infantile protein malnutrition
}

\author{
R. D. MONTGOMERY ${ }^{1}$ \\ From the Medical Research Council Department of Experimental Medicine, \\ University of Cambridge, and Tropical Metabolism Research Unit, Jamaica
}

SYNOPSIS A study was made of the sartorius muscle in Jamaican infants dying of protein malnutrition. Total counts were made of muscle fibres and sub-sarcolemmal nuclei in transverse section and compared with controls.

A striking pathology is found in severe cases. The muscle fibre is reduced to a size comparable with that of the foetus. Although there is a greatly increased concentration of cells, there is also degeneration and actual loss of fibres and of sub-sarcolemmal nuclei. The proportion of the area occupied by muscle bundles may be halved, and there is a marked relative increase in interstitial collagen.

These changes profoundly affect the interpretation of the results of biochemical analysis.

Muscle analysis has proved to be of value in assessing the biochemical changes of nutritional and metabolic disorders (Frenk, Metcoff, Gómez, Ramos-Galván, Cravioto, and Antonowicz, 1957; Waterlow and Mendes, 1957; Montgomery, 1960; Metcoff, Frenk, Antonowicz, Gordillo, and Lopez, 1960; MacIntyre, Hanna, Booth, and Read, 1961). A major difficulty, particularly in studies on infants, is that unproven assumptions regarding the composition of muscle may have to be made in order to establish a basis of reference.

Severe protein malnutrition in infants results in extreme changes in muscle morphology. Histological study of the sartorius muscle in complete crosssection is not only of pathological interest but helps in the understanding of changes in its chemical composition, and of the effect of malnutrition on fibre development.

The sartorius muscle was chosen in this study for two reasons. 1, It is in the form of a strap, and individual fibres possibly extend throughout its length without a junction (Lockhart and Brandt, 1938). Whether or not there are junctions, the number of fibres on transverse section is found to be essentially constant throughout its length. Certain observations made on cross-section can therefore be applied very approximately to the whole muscle by extrapolation. 2, The total number of fibres normally remains constant from early infancy (MacCallum, 1898; Montgomery, 1962). Thus the effect

'Present address: King's College Hospital, Denmark Hill, London S.E.5.

Received for publication 1 June 1962. of malnutrition on development at different ages can be compared without the complicating factor of fibre proliferation.

The only reported study of the histology of striated muscle in kwashiorkor is that of Vincent and Radermecker (1959), who examined biopsy specimens of deltoid and trapezius muscle in Bantu children. Pathological changes in the myocardium in kwashiorkor were described by Bablet and Normet (1937), by Trowell, Davies, and Dean (1954), and by Smythe, Swanepoel, and Campbell (1962).

MATERIAL

Sartorius muscle specimens were obtained at necropsy from six Jamaican infants dying of protein malnutrition between the ages of 8 and 16 months. Their clinical data are summarized in Table I. The term 'protein malnutrition' is taken to include all clinical forms of malnutrition and undernutrition in which deficiency in dietary protein is a dominant factor (Waterlow, 1955). All the subjects of the present study had features of kwashiorkor, except for Case 5 who had shown these signs some months previously but was recovering when death occurred from acute gastro-enteritis. The main criteria for making a diagnosis of kwashiorkor rather than marasmic kwashiorkor were the presence of gross oedema and a grossly enlarged fatty liver.

The body weights ranged from 35 to $75 \%$ of the normal for age, and from 58 to $83 \%$ of the normal for height, 'normal' values being taken from standard tables valid in the United States (Stuart and Stevenson, 1954). As far as could be ascertained, all the babies had been fairly adequately nourished on the breast during the first few months of life, and probably in all of them there had been an actual loss of body weight before death. 
TABLE I

CLINICAL FEATURES OF MALNOURISHED JAMAICAN INFANTS

\begin{tabular}{|c|c|c|c|c|c|c|c|c|c|c|c|c|}
\hline Case & Diagnosis & $\begin{array}{l}\text { Age } \\
\text { (mth.) }\end{array}$ & $\begin{array}{l}\text { Weight } \\
\text { (kg.) }\end{array}$ & $\begin{array}{l}\text { Height } \\
(\mathrm{cm} .)\end{array}$ & $\begin{array}{l}\text { Weight } \\
\% \text { of } \\
\text { Normal } \\
\text { for } \\
\text { Age }^{1}\end{array}$ & $\begin{array}{l}\text { Weight } \\
\% \text { of } \\
\text { Normal } \\
\text { for } \\
\text { Height }^{1}\end{array}$ & Wasting & Oedema & $\begin{array}{l}\text { En- } \\
\text { larged } \\
\text { Liver }\end{array}$ & $\begin{array}{l}\text { Muco- } \\
\text { cutaneous } \\
\text { Ulcera- } \\
\text { tion }\end{array}$ & $\begin{array}{l}\text { Skin } \\
\text { Lesions }\end{array}$ & $\begin{array}{l}\text { Hair } \\
\text { Changes }\end{array}$ \\
\hline 1 & Marasmic kwashiorkor & 8 & $6 \cdot 2$ & 66 & 75 & 83 & + & + & $\therefore$ & + & + & + \\
\hline 2 & Kwashiorkor & 8 & $4 \cdot 6$ & 60 & 56 & 82 & ++ & ++ & $\therefore+$ & + & + & +4 \\
\hline 3 & Marasmic kwashiorkor & 12 & $3 \cdot 5$ & 61 & 35 & 58 & ++ & $\div$ & + & + & o & $\ldots$ \\
\hline 4 & Marasmic kwashiorkor & 13 & $5 \cdot 8$ & 65 & 56 & 80 & ++ & + & o & o & o & o \\
\hline 5 & $\begin{array}{l}\text { Marasmic kwashiorkor } \\
\text { (recovering) }\end{array}$ & 14 & $7 \cdot 5$ & 71 & 72 & 82 & + & o & o & o & o & + \\
\hline 6 & Kwashiorkor & 16 & $5 \cdot 7$ & 69 & 51 & 66 & -+ & $\div+$ & 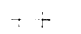 & $\therefore$ & + & $\div$ \\
\hline
\end{tabular}

${ }^{1}$ Normal values for height and weight are taken from American standard tables (Stuart and Stevenson, 1954).

As controls, specimens were taken from full-term and premature stillbirths, from well-nourished infants of 4 and 13 months dying of acute infection, and from Jamaican and European adults.

\section{METHODS}

The whole sartorius muscle was removed, weighed fresh, and fixed in formol-saline. Complete transverse blocks of the muscle were taken from the mid-point and from the distal and proximal quarters of each muscle and mounted in paraffin. Sections of standard thickness were stained with haematoxylin and eosin.

Measurements and counts were made on the stained sections as follows:-

1 Low-power projections of the whole transverse section were made through a photographic enlarger. The outline of the muscle was traced and the area occupied by primary muscle bundles was measured by planimetry, excluding the larger interfascicular spaces and the epimysial tissue. A millimetre scale was similarly projected.

2 High-power images were projected through a standard microscope, using a strong light source, and the scale was obtained from a haemocytometer grid. Counts of individual fibres and of sub-sarcolemmal nuclei were made from fields which included the spaces between secondary and tertiary muscle bundles and were as representative as possible of the total area measured. At least 250 fibres were included in each count (100 in adult cases) and from five to eight separate areas were counted in each section.

As a rough index of the total number of subsarcolemmal nuclei in the whole muscle, the calculated total count in section was multiplied by the body length. This measurement was taken rather than sartorius length, as the specimens in infants were variably shortened in flexion. A discrepancy arises due to differential growth of the thigh relative to the whole body, which tends to underestimate the total nuclear count in adult specimens relative to the others.

3 To obtain approximate values for the area of intracellular and extracellular space, tracings were made as in procedure (1) of the whole cross-section and of the individual tertiary muscle bundles. The area occupied by the latter was then measured by planimetry. This over- $\overrightarrow{0}$ estimates the intracellular space as it includes the extracellular space between individual fibres within the bundle; on the other hand the area of interstitial cells is included in the 'extracellular' space.

Joubert (1956) showed that formalin fixation did not significantly affect the mean diameter of muscle fibres. $\mathbb{\mathbb { D }}$ Fixation may artificially increase the intermysial spaces in adult muscle, but this distortion is very slight in $\overrightarrow{\mathscr{C}}$ specimens from infants. The area of muscle bundles in $\mathrm{N}$ normal infants measured by planimetry was 66 to $72 \%$ of $\square$ the whole area. This may be compared with reported figures of 70 and $71 \%$ for the intracellular volume of normal children's muscle (Frenk, Metcoff, Gómez, Ramos-Galván, Cravioto, and Antonowicz, 1957; Dickerson and Widdowson, 1960) as calculated from the chloride space.

\section{RESULTS}

OVERALL CHANGES The most striking morphological changes observed in transverse section were extreme reduction in cross-section area of the sartorius muscle relative to the normal for age (Fig. 1); reduction in the area occupied by muscle bundles relative to the whole (Fig. 2); and extreme reduction in the size of individual muscle fibres relative to the normal, with crowding of the sub-sarcolemmal nuclei (Figs. 2 to 5). Blood vessels, nerves, and muscle spindles were also crowded and were not 0 proportionately reduced in size (Figs. 6 and 7).

THE INTERMYSIAL TISSUE Extracellular area was relatively increased, both in the major and minor interfascicular spaces and between the individual fibres (Fig. 2). These spaces were extensively $\&$ occupied by connective tissue of poor or moderate cellularity in contrast to the clear unstained spaces interspersed with thin strands of collagen which are found in the normal. Some specimens also showed a relative increase in interfascicular adipose tissue (Fig. 8). The crowding of arterioles and capillaries

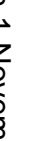




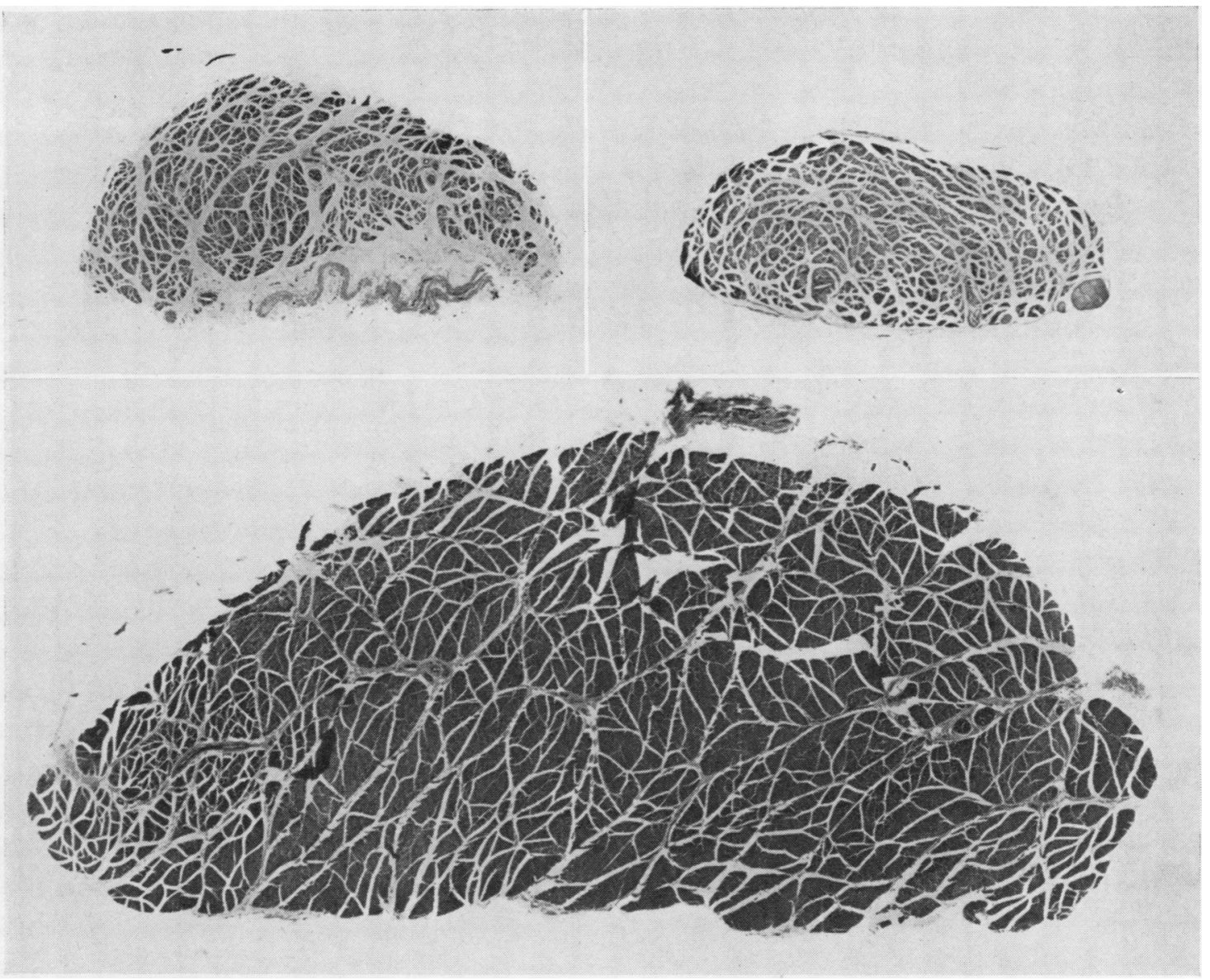

FIG. 1. Transverse section of whole sartorius muscle in Case 3, a malnourished infant aged 12 months (top left), compared with that of a foetus at 31 weeks' gestation (top right) and a well-nourished infant aged 13 months (below). (Haemato$x y$ lin and eosin $\times 16$.

caused an apparent increase in vascularity; the lumina tended to be narrower than in age controls, thus giving an apparent increase in the cellularity of the vessel walls. No aggregation of lymphocytes or histiocytes was found either perivascularly or elsewhere.

THE MUSCLE BUNDLES In severe cases the individual muscle fibres were reduced to a size comparable with that found in late foetal life (Figs. 2, 5). There was a notable variation in the size of the fibres, as is also found in foetal specimens. Part of this variation, however, was due to the presence of swollen degenerate fibres exhibiting loss of striation and eosinophilic staining, accompanied by degeneration and loss of sub-sarcolemmal nuclei (Figs. 8 to 10). Some of the degenerate nuclei were rounded and pyknotic, but others were pale and amorphous, tending to a rectangular shape. In the final stage there was clumping and fragmentation of the nuclear material, while the fibre outline merged into the collagenous matrix, often irregularly, giving an effect of 'fragmentation' (Fig. 9).

Striation of the fibres was often preserved to a late stage. Apparently viable nuclei of subsarcolemmal type were sometimes seen to persist in extremely degenerate fibres. In no cases were centrally placed fibre nuclei found.

The loss of fibres did not depend entirely on severity as judged by the deficit in body weight, muscle weight, or fibre size. Thus in Case 4, whose body weight was $56 \%$ of the normal for age, there was more cell destruction, with numerous eosinophilic fibres and almost universal loss of striation, 

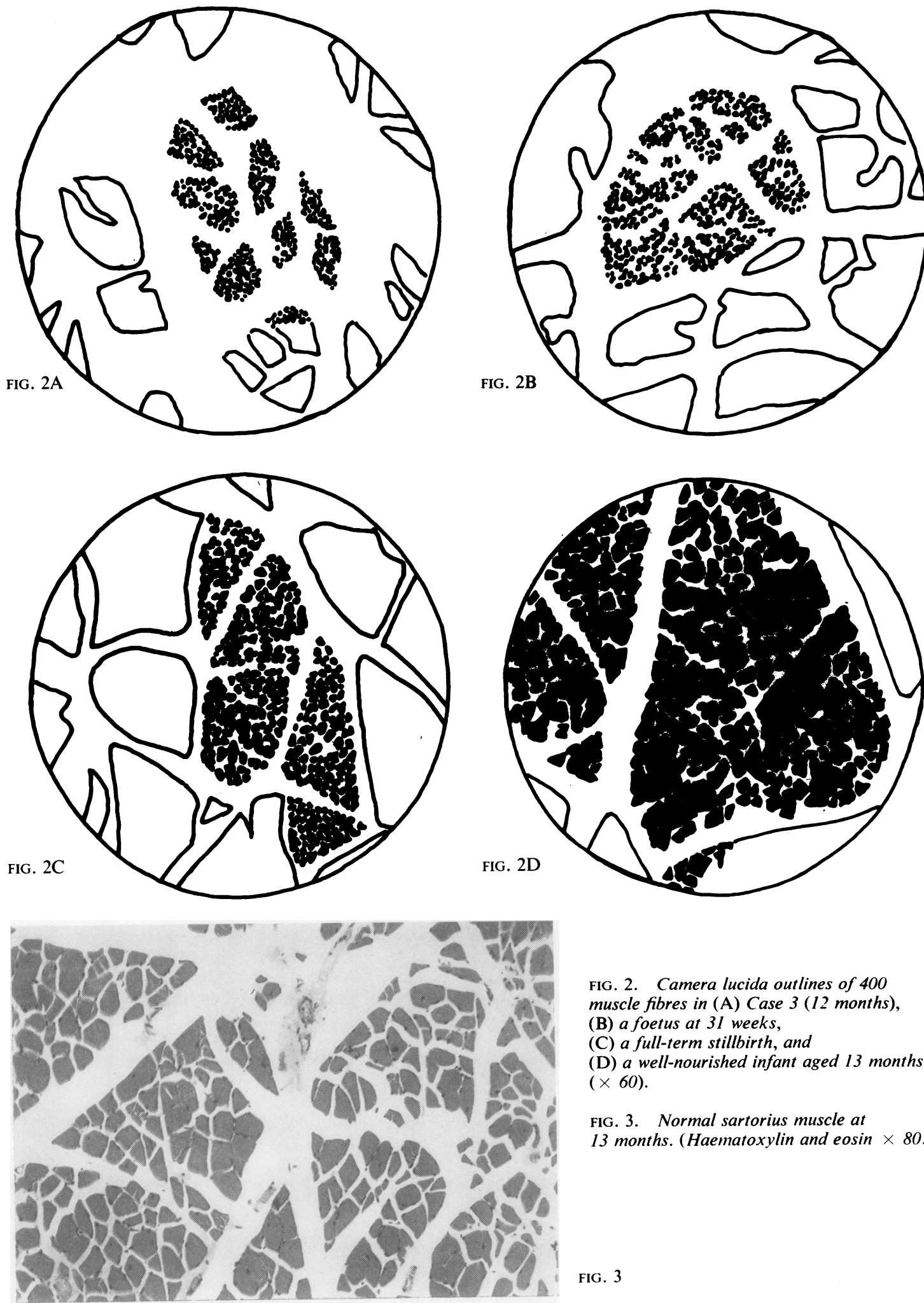

FIG. 2. Camera lucida outlines of 400 muscle fibres in (A) Case 3 (12 months),

(B) a foetus at 31 weeks,

(C) a full-term stillbirth, and

(D) a well-nourished infant aged 13 months $(\times 60)$

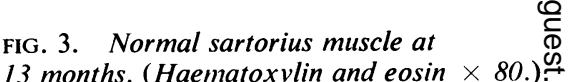



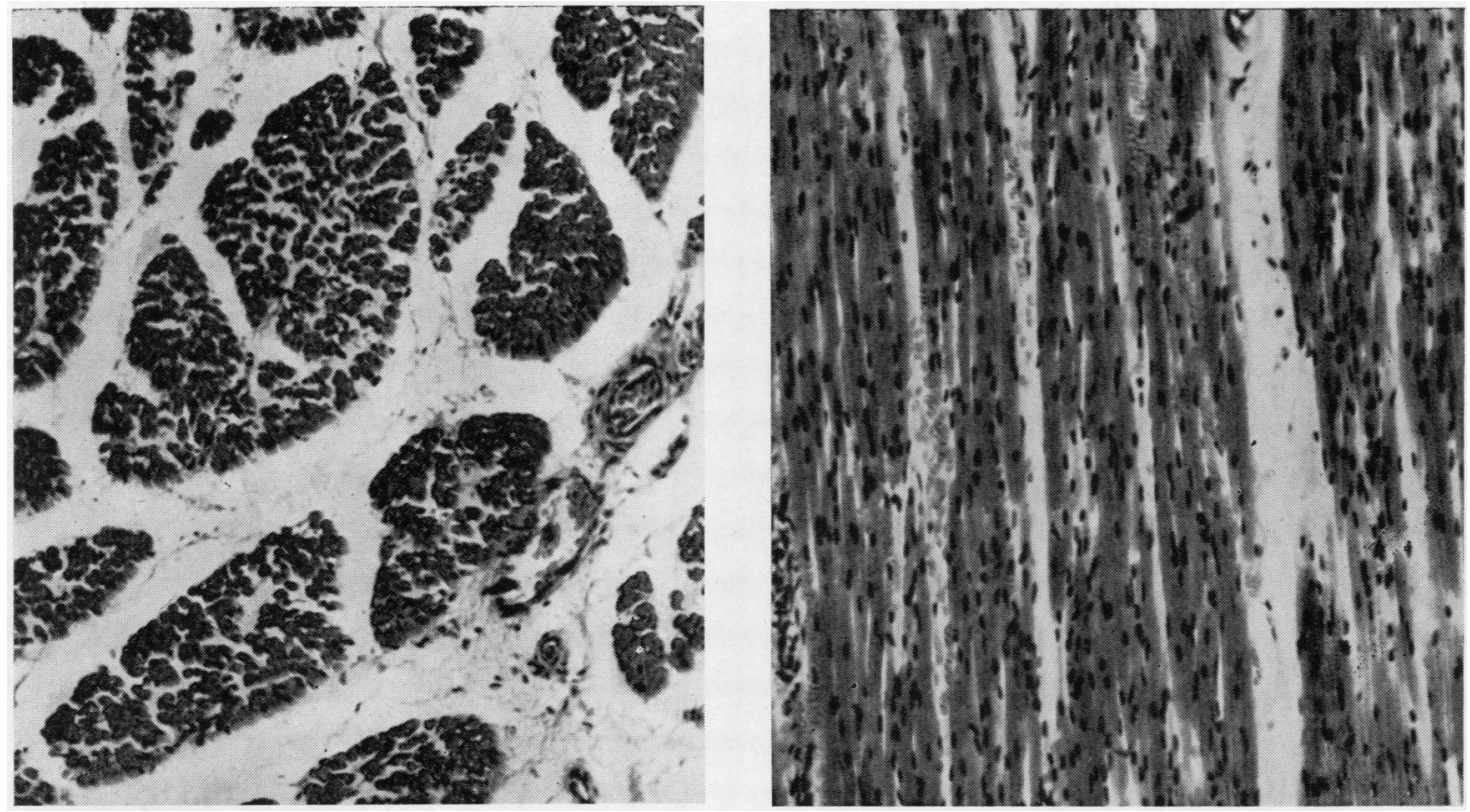

FIG. $4 \mathrm{a}$

FIG. 4b

FIG. 4. Normal sartorius muscle in a foetus at 31 weeks. (a) Transverse section. (b) Longitudinal section. (Haematoxylin and eosin $\times 120$.)

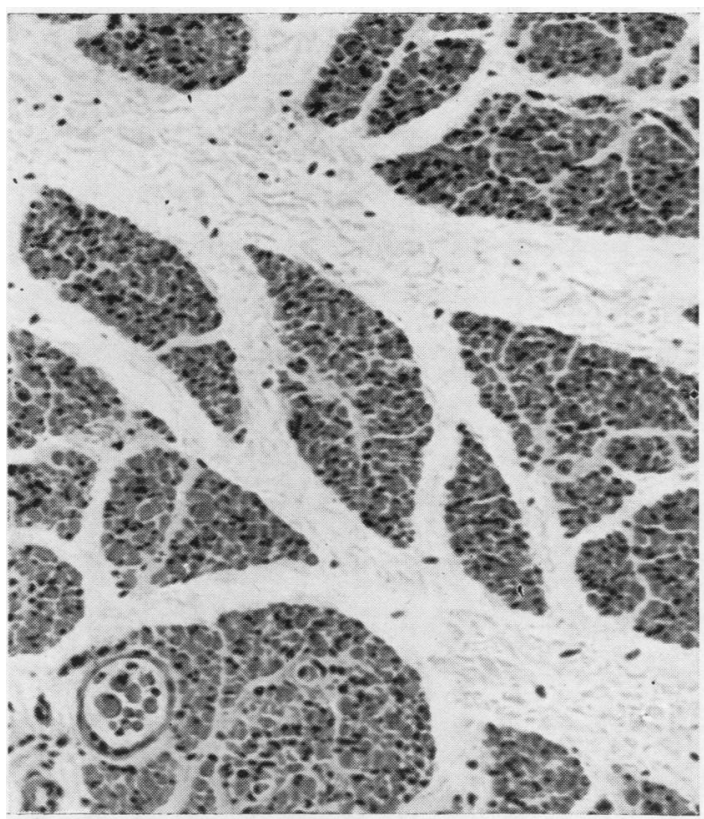

FIG. 5a

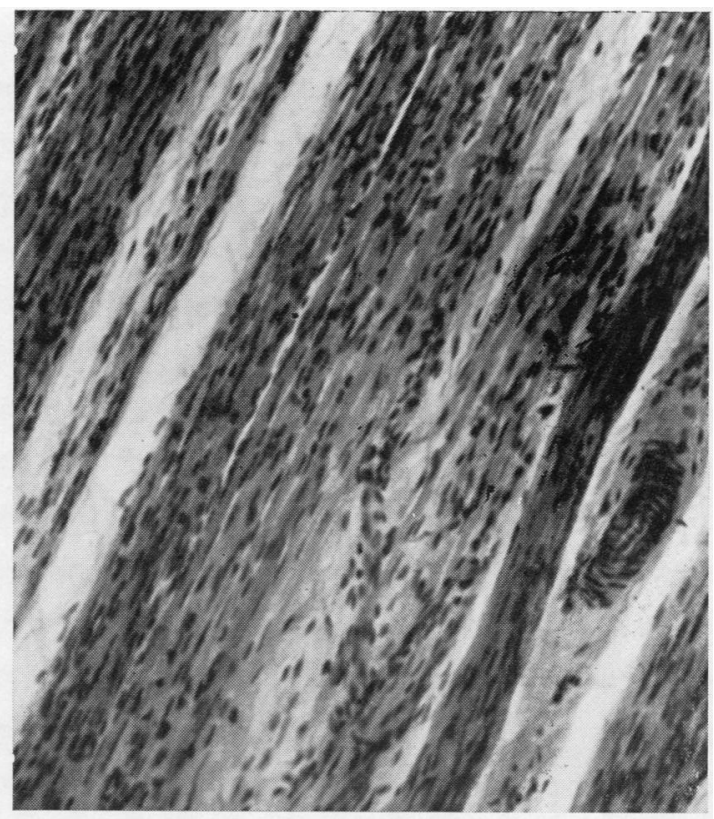

FIG. $5 b$

FIG. 5. Sartorius muscle, Case 3 (12 months). (a) Transverse section. (b) Longitudinal section showing reduction in fibre size, crowding of nuclei, and increase in interfascicular connective tissue. Striation of fibres is wall preserved. (Haematoxylin and eosin $\times 120$.) 


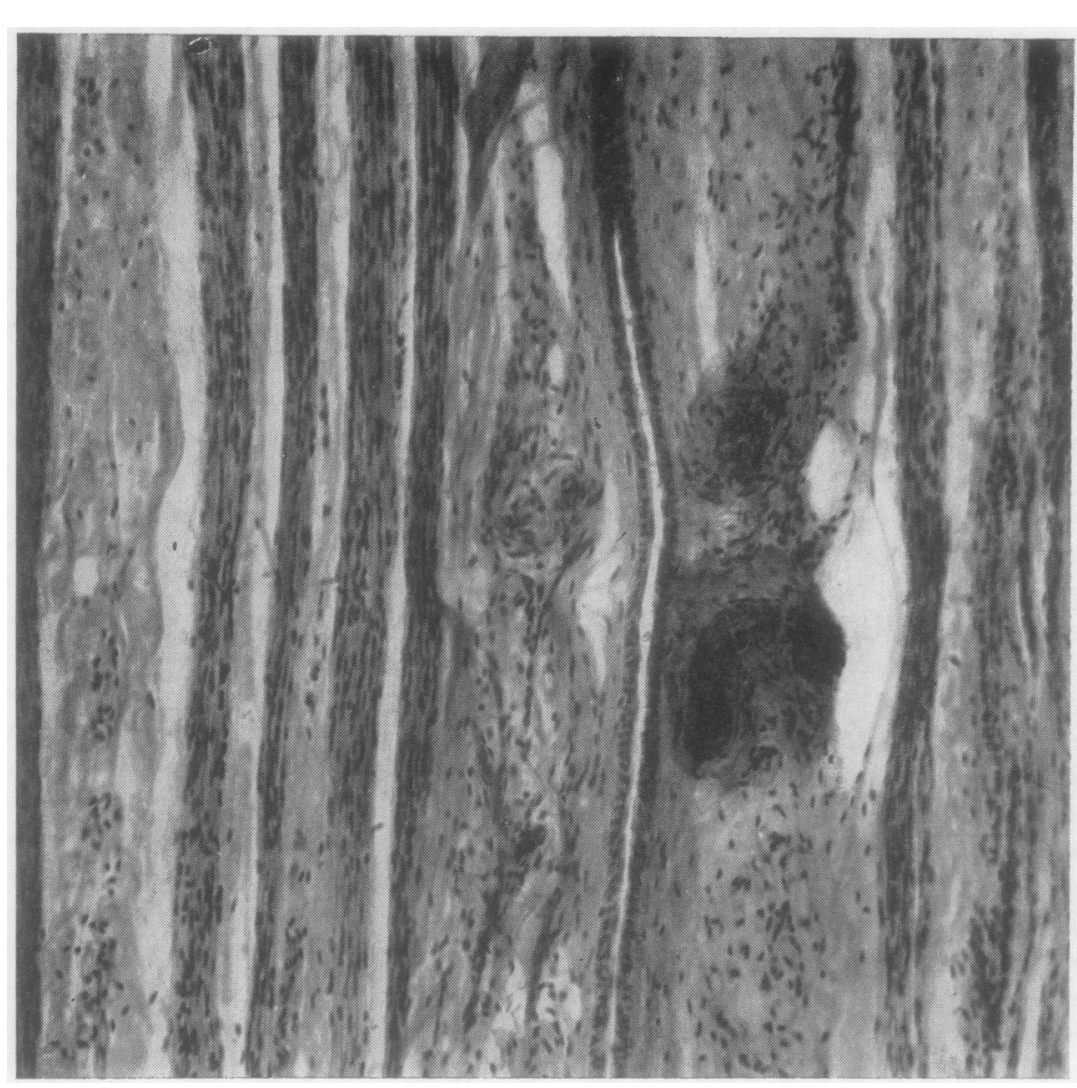

FIG. 6

FIG. 7

FIG. 6. Longitudinal section, Case 2 ( 8 months), showing small fibres in a predominantly fibrous stroma, with normal capillaries. (Haematoxylin and eosin $\times 70$.)

FIG. 7. Sartorius muscle, Case 4, aged 13 months, severe malnutrition. (Haematoxylin and eosin $\times 16$.

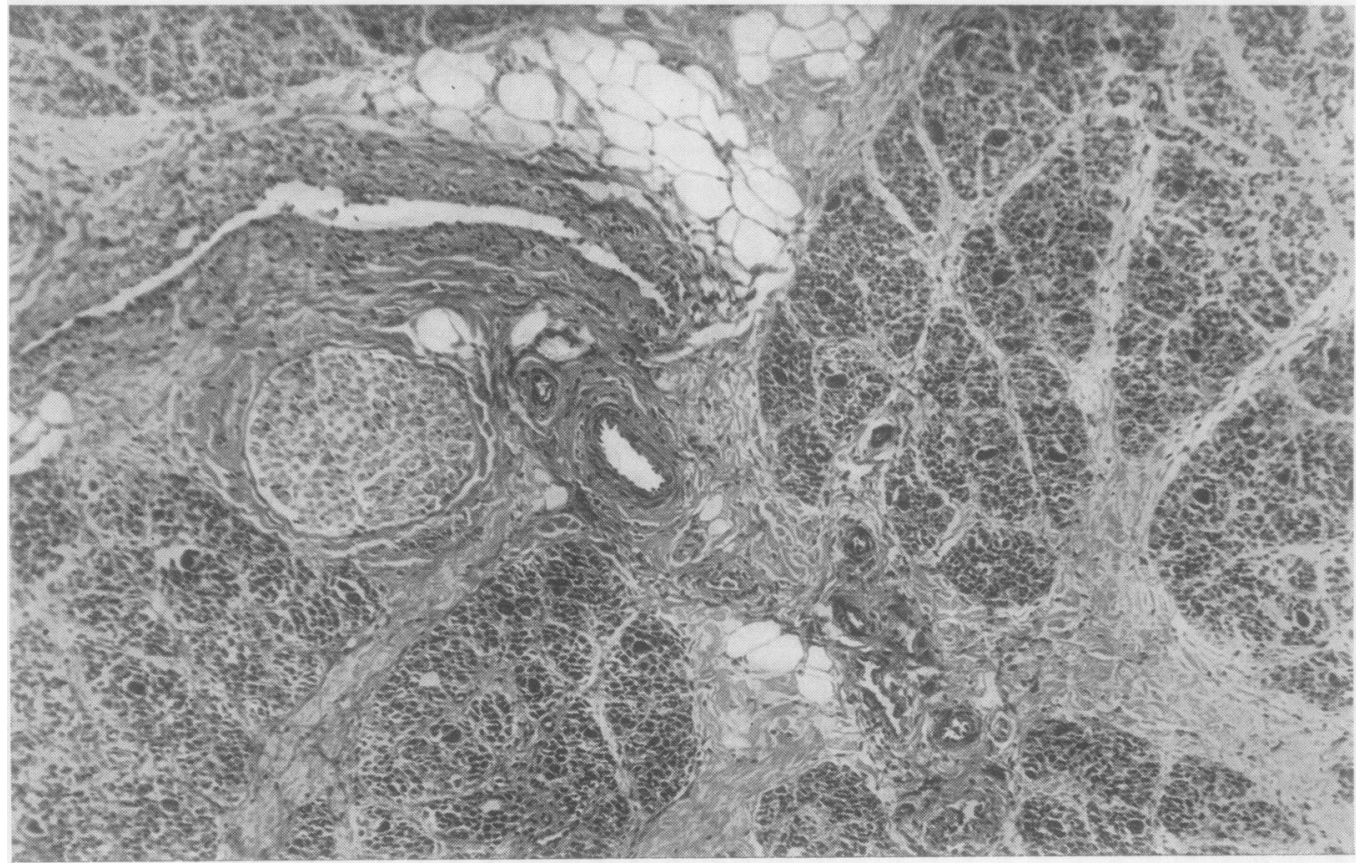

FIG. 8. Case 4, showed marked relative increase in fibrous tissue and fat, and numerous swollen degenerate fibres. (Haematoxylin and eosin $\times 60$.)

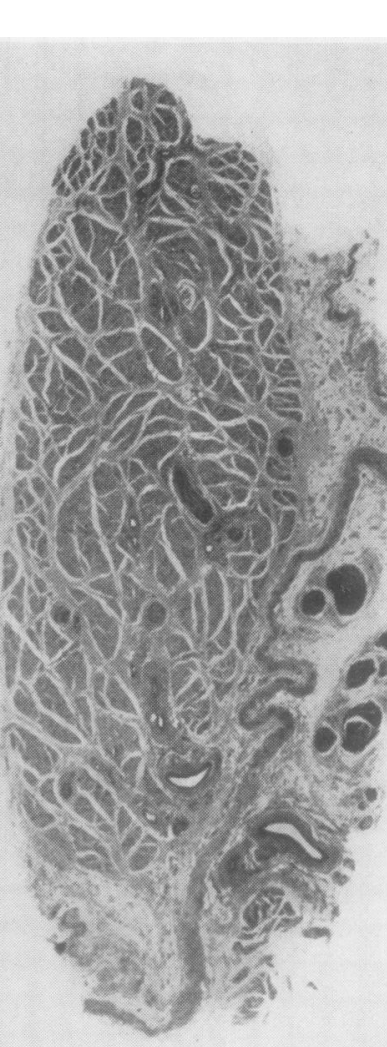




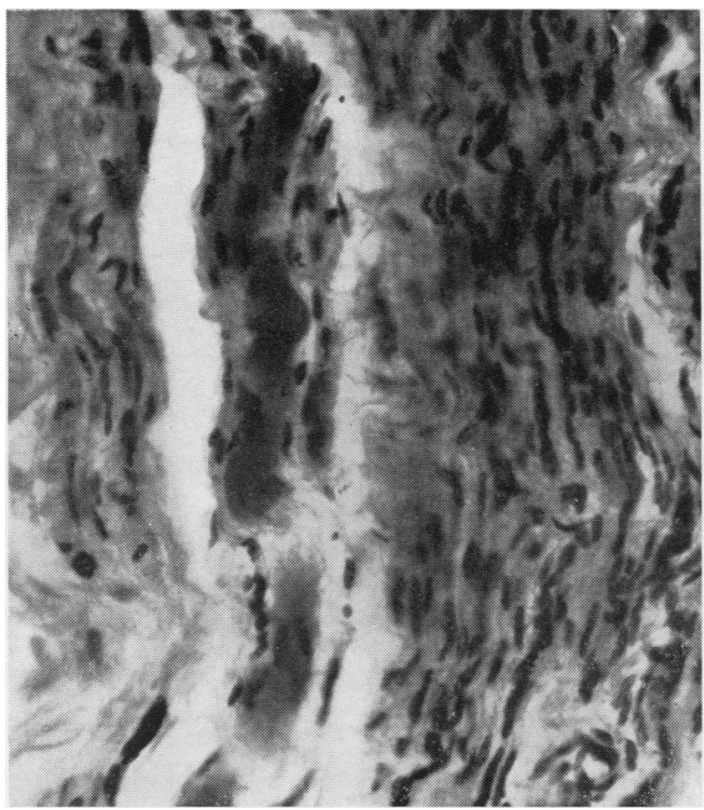

FIG. 9. Fragmentation and eosinophilic change in a swollen fibre. There is widespread loss of striation and fibre outlines. Longitudinal section, Case 4. (Haematoxylin and eosin $\times 160$.)

FIG. 10. Case 6 (aged 16 months). The pathology is similar to that of Case 4. (Haematoxylin and eosin $\times 160$.)

FIG. 9

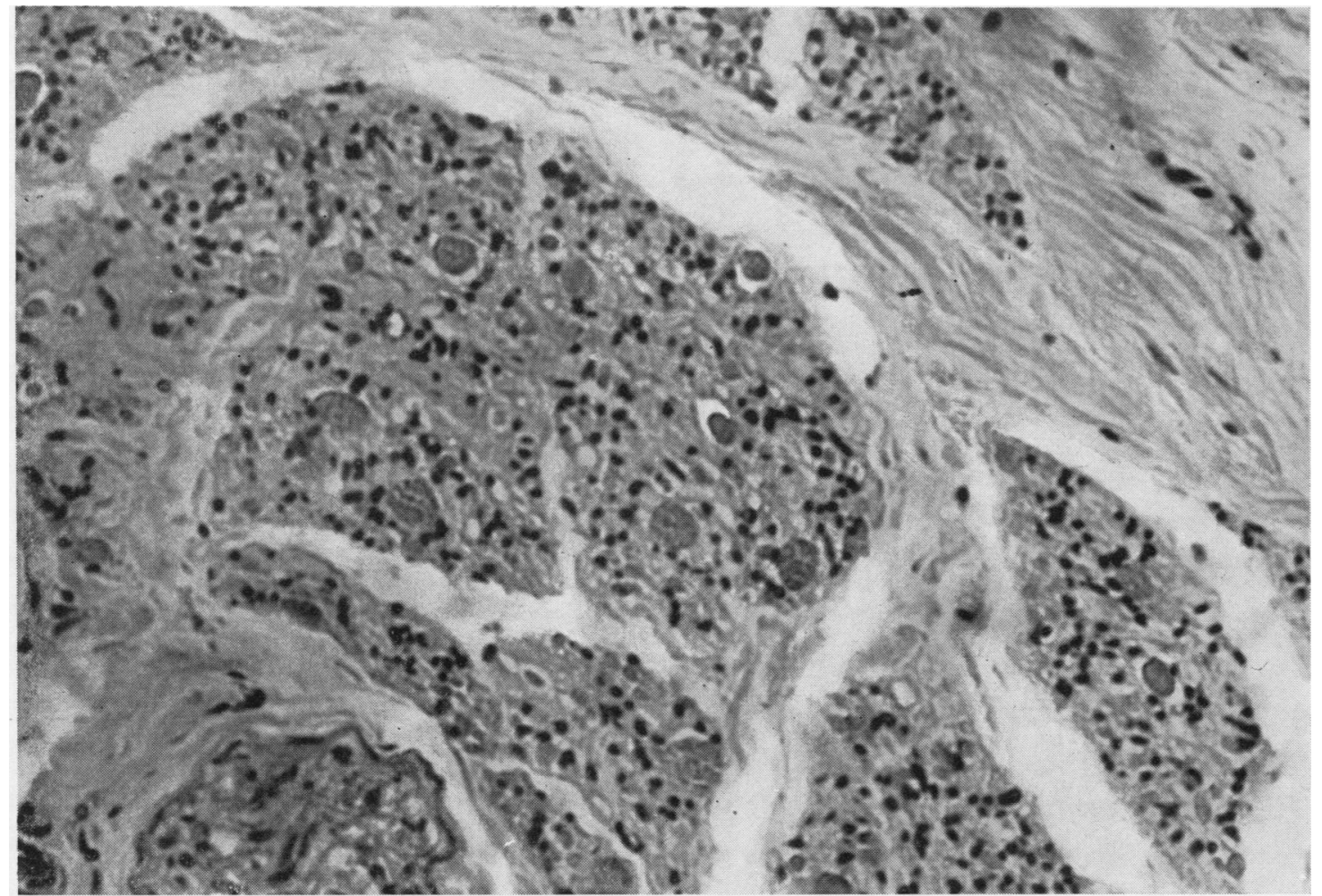

FIG. 10 
TABLE II

TOTAL COUNTS OF FIBRES AND SUB-SARCOLEMMAL NUCLEI IN TRANSVERSE SECTION OF SARTORIUS MUSCLE IN MALNOURISHED INFANTS AND CONTROLS

\begin{tabular}{|c|c|c|c|c|}
\hline Case & Age & $\begin{array}{l}\text { Weight } \% \text { of Normal } \\
\text { for Age }\end{array}$ & $\begin{array}{l}\text { Mean No. of Fibres } \\
\pm \text { Standard Error (thousands) }\end{array}$ & $\begin{array}{l}\text { Mean No. of Nuclei } \\
\pm \text { Standard Error (thousands) }\end{array}$ \\
\hline $\begin{array}{l}1 \\
2 \\
3 \\
4 \\
5 \\
6\end{array}$ & $\begin{array}{l}8 \mathrm{mth} . \\
8 \mathrm{mth} . \\
12 \mathrm{mth} . \\
13 \mathrm{mth} . \\
14 \mathrm{mth} . \\
16 \mathrm{mth} .\end{array}$ & $\begin{array}{l}75 \\
56 \\
35 \\
56 \\
72 \\
51\end{array}$ & $\begin{array}{r}45 \pm 5 \cdot 30 \\
60 \pm 5 \cdot 12 \\
60 \pm 1 \cdot 16 \\
?^{1} \pm \\
88 \pm 2 \cdot 30 \\
102 \pm 4 \cdot 22\end{array}$ & $\begin{array}{l}45 \pm 4 \cdot 13 \\
51 \pm 2 \cdot 16 \\
48 \pm 1 \cdot 45 \\
52 \pm 5 \cdot 17 \\
61 \pm 2 \cdot 99 \\
59 \pm 2 \cdot 33\end{array}$ \\
\hline $\begin{array}{l}\text { Controls } \\
\text { Jamaican } \\
\text { Jamaican } \\
\text { Jamaican } \\
\text { Jamaican } \\
\text { European } \\
\text { European } \\
\text { Jamaican } \\
\text { Jamaican } \\
\text { Jamaican }\end{array}$ & $\begin{array}{l}31 / 52 \text { foetus } \\
33 / 52 \text { foetus } \\
40 / 52 \text { stillbirth } \\
4 \mathrm{mth} \text {. } \\
13 \mathrm{mth} . \\
64 \mathrm{yr} . \\
74 \mathrm{yr} . \\
54 \mathrm{yr} . \\
65 \mathrm{yr} .\end{array}$ & & $\begin{array}{c}64 \pm 3 \cdot 15 \\
76 \pm 2 \cdot 09 \\
101 \pm 4 \cdot 75 \\
134 \pm 7 \cdot 36 \\
128 \pm 5 \cdot 35 \\
103 \pm 3 \cdot 59 \\
114 \pm 2 \cdot 70 \\
98 \pm 5 \cdot 03 \\
54 \pm 2 \cdot 37^{2}\end{array}$ & $\begin{array}{c}34 \pm 2 \cdot 10 \\
42 \pm 2 \cdot 29 \\
56 \pm 1 \cdot 27 \\
64 \pm 2 \cdot 58 \\
85 \pm 2 \cdot 59 \\
233 \pm 9 \cdot 84 \\
201 \pm 10 \cdot 45 \\
203 \pm 12 \cdot 40 \\
117 \pm 5 \cdot 23^{2}\end{array}$ \\
\hline
\end{tabular}

${ }^{1}$ Fibres could not be counted accurately due to gross pathology.

${ }^{2}$ See discussion.

TABLE III

AREA MEASUREMENTS, FIBRE COUNTS, AND NUCLEAR COUNTS IN TRANSVERSE SECTIONS OF THE WHOLE SARTORIUS MUSCLE IN A MALNOURISHED INFANT AND CONTROLS

\begin{tabular}{|c|c|c|c|c|c|c|c|c|}
\hline \multirow[t]{2}{*}{ Case } & \multirow[t]{2}{*}{ Age } & \multirow{2}{*}{$\begin{array}{l}\text { Body } \\
\text { Weight } \\
(\text { kg.) }\end{array}$} & \multirow{2}{*}{$\begin{array}{l}\text { Body } \\
\text { Length } \\
(\mathrm{cm} .)\end{array}$} & \multicolumn{5}{|c|}{ Sartorius Cross-section } \\
\hline & & & & $\begin{array}{l}\text { Total Area } \\
(s q . \mathrm{mm} .)\end{array}$ & $\begin{array}{l}\text { Area of } \\
\text { Fibre Bundles } \\
\text { (sq. mm.) }\end{array}$ & $\begin{array}{l}\text { Total Fibres } \\
\text { (thousands) }\end{array}$ & $\begin{array}{l}\text { Total Sub- } \\
\text { sarcolemmal } \\
\text { Nuclei } \\
\text { (thousands) }\end{array}$ & $\begin{array}{l}\text { Nuclei } \times \\
\text { Body Length } \\
\quad\left(\times 10^{-5}\right)^{1}\end{array}$ \\
\hline $\begin{array}{l}31 / 52 \text { premature foetus } \\
\text { Full-term stillbirth } \\
\text { Marasmic kwashiorkor } \\
\text { Well-nourished infant } \\
\text { Adult }\end{array}$ & $\begin{array}{l}- \\
\overline{12} \mathrm{mth} . \\
13 \mathrm{mth} . \\
74 \mathrm{yr} .\end{array}$ & $\begin{array}{c}1 \cdot 6 \\
3 \cdot 1 \\
3 \cdot 5 \\
9 \cdot 5 \\
56\end{array}$ & $\begin{array}{r}38 \\
50 \\
61 \\
76 \\
156\end{array}$ & $\begin{array}{r}5 \cdot 6 \\
16 \cdot 3 \\
6 \cdot 4 \\
39 \cdot 4 \\
220\end{array}$ & $\begin{array}{l}2 \cdot 2 \\
9 \cdot 8 \\
2 \cdot 1 \\
28 \cdot 3 \\
133\end{array}$ & $\begin{array}{r}64 \\
101 \\
60 \\
128 \\
114\end{array}$ & $\begin{array}{r}34 \\
56 \\
48 \\
85 \\
201\end{array}$ & $\begin{array}{r}13 \\
28 \\
29 \\
65 \\
313\end{array}$ \\
\hline
\end{tabular}

${ }^{1}$ An approximate index of total sub-sarcolemmal nuclei in the whole muscle (see text)

than in Case 3 whose fibres were on the whole smaller but striated, and whose body weight was $35 \%$ of normal (Figs. 5,8 ).

FIBRE AND NUCLEAR COUNTS The total numbers of muscle fibres and sub-sarcolemmal nuclei in sections of sartorius muscle in malnourished infants and controls are shown in Table II. Contrary to earlier belief (MacCallum, 1898), it is evident that in normal human muscle an increase in the number of fibres on transverse section may continue through late foetal life. Adult numbers, however, are clearly reached by the age of 4 months.

In severe malnutrition there may be a loss of over $50 \%$ of the fibres. Sub-sarcolemmal nuclear counts per section tend to show a lesser decrease, of the order 60 to $70 \%$. The total nuclear numbers in the muscle will also depend on skeletal length (Table III, final column), and Fig. 11 illustrates the approximate deficit in the individual cases. In spite of this deficit there may be an eight-fold concentration of nuclei in the malnourished specimen.

\section{DISCUSSION}

HISTOPATHOLOGY Vincent and Radermecker (1959) concluded that the earliest abnormal finding in kwashiorkor was hyperplasia of the sub-sarcolemmal nuclei, which was followed by increase in size of the capillary endothelial nuclei and proliferation of the interfascicular 'dark' nuclei, presumably the fibroblasts of the endomysial sheath. No evidence of these changes could be found in the present study. Such appearances could be attributed to crowding of the cells, and as shown above there was always an overall loss of sub-sarcolemmal nuclei. In severe cases there appeared to be a moderate increase in interfascicular fibroblasts and in endomysial nuclei in the neighbourhood of degenerating fibres, but again it may be incorrect to speak of an overall 


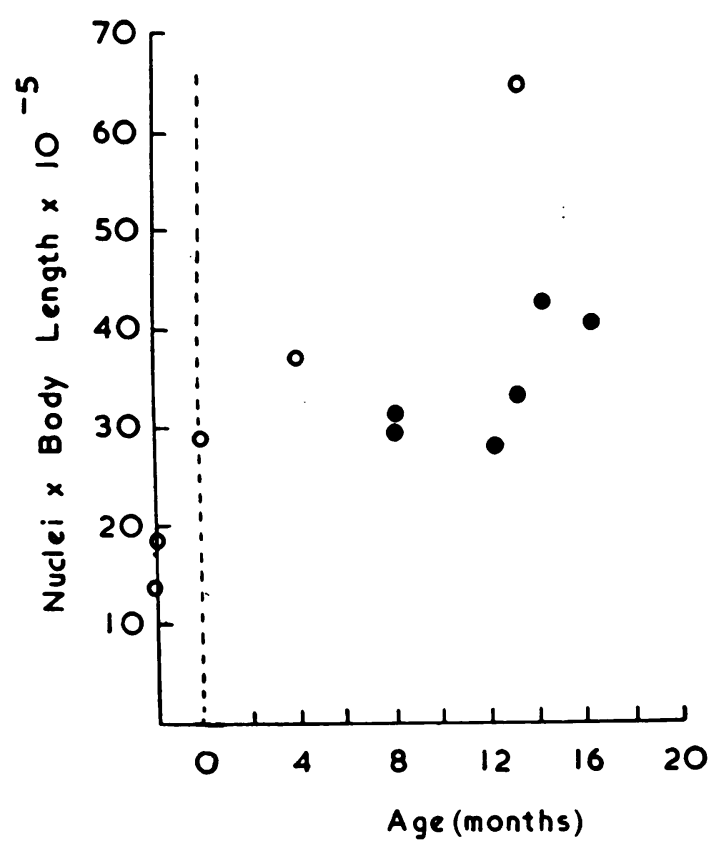

FIG. 11. An index of total numbers of sub-sarcolemmal nuclei in sartorius muscle at different ages.

$=$ malnourished infants

$\mathrm{O}=$ controls (premature stillbirths and well-nourished infants)

increase in view of the reduction in size of the muscle.

Eosinophilic degeneration of fibres, which was found by Vincent and Radermecker only in rare isolated fibres, was widespread in the most severe cases of this series. The material of these authors was obtained by biopsy from older African children and from different muscles, and the degree of wasting was probably less extreme. Two of their five cases which were reported to show a moderate degree of muscle pathology were not cases of kwashiorkor, and one of these had no evidence of muscle wasting.

FIBRE NUMBERS There are no known clinical sequelae of protein malnutrition, except for a possible long-term effect on stature (Brock, 1961). The finding of a serious loss of muscle cells, however, raises the question of whether this deficit may be permanent. Fibre counts in adult Jamaican controls (Table II) suggest that this might be so. In two Jamaican cases the total number of fibres in the sartorius was comparable to that found in the infant controls, in a European adult, and as reported by MacCallum (1898), very approximately 120,000 . In another, however, the number was reduced to 54,000 . This adult was moderately wasted at death, but the muscle fibres were uniformly large and their mean diameter was greater than that of the other controls. The histological picture was normal and there was nothing to suggest a recent loss of fibres. From what was known of the patient's social history, he might well have suffered from malnutrition in infancy.

MUSCLE PROTEINS The greatly increased collagen content of muscle in kwashiorkor has been confirmed by analysis (Dr. J. W. T. Dickerson, unpublished data). It is open to two explanations: 1 , That when growth is interrupted by lack of dietary protein the development of the more metabolically active intracellular proteins is disproportionately retarded in comparison with that of collagen (Waterlow, Cravioto, and Stephen, 1960). 2, That when there is an actual demand for mobilization of body protein the collagen is less 'mobile' than other protein and is left behind.

An exact history of the acuteness of the wasting process is seldom clear in human subjects. The two alternatives are basically similar, and both may apply.

In weanling rats whose weight gain was retarded on a simulated Jamaican infants' diet, the collagen content of gastrocnemius muscle increased from approximately 3 to $34 \%$ of all protein (Mendes and Waterlow, 1958). In young pigs severely undernourished on a balanced diet extracellular protein increased from 3 to $70 \%$ (Widdowson, Dickerson, and McCance, 1959). In the growing cockerel the proportion of extracellular protein reached $14 \%$ when weight gain was inhibited, and $20 \%$ when one-third of the body weight was lost through acute undernutrition (Dickerson and McCance, 1960). It must be borne in mind that these studies involved different muscles and diets and that there may be species differences in the behaviour of collagen.

MUSCLE ELECTROLYTES Hansen (1956) concluded from balance studies that in infantile protein malnutrition there is an excessive accumulation of water, sodium, and chloride in the body and an overall deficit of potassium. These findings have been supported by estimations of total body water (Schnieden, Hendrickse, and Haigh, 1958; Smith, 1960) and total exchangeable potassium (Smith and Waterlow, 1960). Similar changes are found in analysis of muscle (Frenk, Metcoff, Gómez, RamosGalván, Crovioto, and Antonowicz, 1957; Waterlow and Mendes, 1957); and it is also known that a deficit of muscle magnesium parallels or may exceed that of potassium (Montgomery, 1960; Metcoff, Frenk, Antonowicz, Gordillo, and Lopez, 1960). 
TABLE IV

RELATION OF ELECTROLYTE CONTENTS TO DISTRIBUTION OF TISSUE FLUIDS IN TWO HYPOTHETICAL CASES COMPARED WITH FINDINGS IN A SERIES OF MALNOURISHED INFANTS

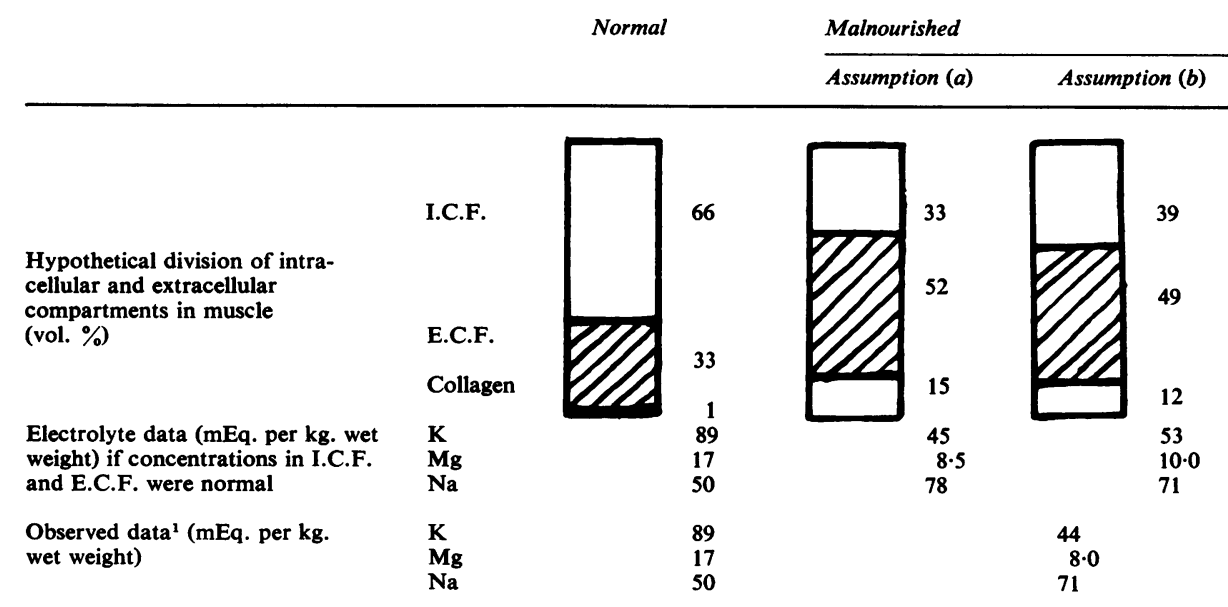

'Data from Montgomery $(1960,1961)$ and Dickerson and Widdowson (1960).

The infant may present the apparent paradox of an overall excess of water and sodium in the presence of clinical dehydration and low levels of serum sodium. Waterlow and Mendes (1957) concluded that the excess of water was confined to the extracellular phase. An increase in the thiocyanate space is well recognized in all forms of undernutrition (Kerpel-Fronius and Kovach, 1948; Widdowson and McCance, 1951; Gopalan, Venkatachalam, and Srikantia, 1953; Holmes, Jones, Lyle, and Stanier, 1956). Frenk and his colleagues in Mexico calculated on the basis of the chloride space that in severe infantile malnutrition there is also intracellular overhydration with lowered potassium concentration, and that intracellular sodium is increased. Pille (1957) reached similar conclusions in West Africa. The finding of serum hypotonicity (Metcoff, Frenk, Gordillo, Gómez, Ramos-Galván, Cravioto, Janeway, and Gamble, 1957; Waterlow, 1961) also suggests that intracellular cations are decreased in relation to cell water. On a basis of non-collagen nitrogen, a deficit of potassium was found by Frenk et al. (1957) and by Waterlow and Mendes (1957) and of magnesium and inorganic phosphorus by Metcoff et al. (1960).

Whatever may be the changes due to protein malnutrition per se, it is reasonable to suppose that the alimentary electrolyte losses frequently accompanying the condition may be reflected in the intracellular cations.

The present study, while in no way refuting these findings, emphasizes that changes in electrolyte composition must always be viewed in the light of altered muscle morphology. Planimetry suggests that $\stackrel{\oplus}{\circ}$ in the malnourished specimen the intracellular space may readily be halved and the extracellular 0 space doubled, the latter including an increased component of collagen. In terms of wet weight, therefore, the finding of half the normal concentrations of intracellular cations, and of a great $\stackrel{\Phi}{2}$ increase in sodium despite low serum sodium levels, $\overrightarrow{\overrightarrow{0}}$ does not necessarily indicate any disturbance of the intracellular milieu. Nor can findings based on dry fat-free solids or total nitrogen be conclusive owing? to the increased proportion of extracellular protein. Accurate estimation of non-collagen nitrogen is:very difficult in small specimens; moreover this is not a very satisfactory basis of reference in growing muscle (Dickerson and Widdowson, 1960).

Another factor to be considered in malnourished $\circ$ muscle is the abnormally high proportion of nuclear material with its own protein and electrolyte composition.

During recovery the rise in intracellular electrolyte $\mathcal{N}$ contents will be proportionately greater than the fall $N$ in extracellular, if the concentrations of the latter N were initially subnormal. This has been found in practice (Montgomery, 1961).

Table IV illustrates the effects of malnutrition on the intracellular and extracellular compartments in two hypothetical cases. The electrolyte contents to be expected on a basis of normal concentrations within these compartments are compared with the actual $\mathbb{\mathbb { D }}$ results obtained in a series of biopsy specimens. It $\frac{\rho}{\mathbb{\Phi}}$ can be seen that small errors in the calculation of $\varrho$ the extracellular space can greatly affect the inter- 
pretation. On assumption (a) the observed data indicate normal intracellular concentrations, and the extracellular sodium content represents a serum concentration of about $127 \mathrm{mEq}$. per litre, as is frequently found. If the volume distribution were as in (b) however, the observed figures represent a $20 \%$ fall in intracellular electrolyte concentration, and are compatible with the entry of sodium into the cell.

I am grateful to Mrs. Eva Jalucek for the meticulous preparation of histology slides, and to Messrs. Ilford Ltd. for photomicrography.

\section{REFERENCES}

Bablet, J., and Normet, L. (1937). Bull. Acad. Méd. (Paris), 117, 242. Brock, J. F. (1961). Recent Advances in Human Nutrition, p. 138. Churchill, London.

Dickerson, J. W. T., and McCance, R. A. (1960). Brit. J. Nutr., 14, 331 .

, and Widdowson, E. M. (1960). Biochem. J., 74, 247.

Frenk, S., Metcoff, J., Gómez, F., Ramos-Galván. R., Cravioto, J., and Antonowicz, I. (1957). Pediatrics, 20, 105.

Gopalan, C., Venkatachalam, P. S., and Srikantia, S. G. (1953) Metabolism, 2, 335.

Hansen, J. D. L. (1956). S. Afr. J. lab. clin. Med., 2, 206.

Holmes, E. G., Jones, E. R., Lyle, M. D., and Stanier, M. W. (1956). Brit. J. Nutr., 10, 198

Joubert, D. M. (1956). J. agric. Sci., 47, 59.

Kerpel-Fronius, E., and Kovach, S. (1948). Pediatrics, 2, 21

Lockhart, R. D., and Brandt, W. (1938). J. Anat. (Lond.), 72, 470.
MacCallum, J. B. (1898). Bull. Johns Hopk. Hosp., 9, 208.

MacIntyre, I., Hanna, S., Booth, C. C., and Read, A. E. (1961). Clin. Sci., 20, 297.

Mendes, C. B., and Waterlow, J. C. (1958). Brit. J. Nutr., 12, 74.

Metcoff, J., Frenk, S., Antonowicz, I., Gordillo, G., and Lopez, E. (1960). Pediatrics, 26, 960.

Gordillo, G., Gómez, F., Ramos-Galván, R., Cravioto, J., Janeway, C. A., and Gamble, J. L. (1957). Ibid., 20, 317.

Montgomery, R. D. (1960). Lancet, 2, 74.

(1961). J. Pediat., 59, 119.

(1962). Nature (Lond.), 195, 194.

Pille, G. (1957). Le contrôle du traitment du kwashiorkor au laboratoire de biochimie clinique. Importance des facteurs électrolytiques, p. 116. Direction Générale de la Santé Publique, Dakar.

Schnieden, H., Hendrickse, R. G., and Haigh, C. P. (1958). Trans. roy. Soc. trop. Med. Hyg., 52, 169.

Smith R. (1960). Clin. Sci., 19, 275.

- , and Waterlow, J. C. (1960). Lancet, 1, 147.

Smythe, P. M., Swanepoel, A., and Campbell, J. A. H. (1962). Brit. med. J., 1, 67.

Stuart, H. C., and Stevenson, S. S. (1954). In Textbook of Pediatrics, od. W. E. Nelson, 6th ed., p. 54. Saunders, Philadelphia.

Trowell, H. C., Davies, J. N. P., and Dean, R. F. A. (1954). Kwashiorkor, p. 153. Arnold, London.

Vincent, M., and Radermecker, M. A. (1959). Amer. J. trop. Med. Hyg., 8, 511.

Waterlow, J. C. (1955). Protein Malnutrition. Proceedings of a Conference in Jamaica, 1953, edited by J. C. Waterlow (for Food and Agriculture Organization, World Health Organization, and Josiah Macy Jr. Foundation.) University Press, Cambridge.

- (1961). Personal communication.

, Cravioto, J., and Stephen, J. M. L. (1960). In Advances in Protein Chemistry, Vol. 15, p. 179. Academic Press, New York.

Widdowson, E. M., Dickerson, J. W. T., and McCance, R. A. (1959). Brit. J. Nutr., 14, 457.

- and McCance, R. A. (1951). In Studies of Undernutrition, Wuppertal, 1946-49. Spec. Rep. Ser. med. Res. Coun. (Lond.), No. 275 , p. 165. H.M.S.O., London. 